\title{
An obesrvational study to compare bala in Adana and visarga kaala with respect to physiological parameters
}

\author{
Research Article
}

\section{Bindu K Viswambharan ${ }^{*}$, Abhilash M², Anny Yohannan ${ }^{3}$}

1. Assistant Professor, 2. Assistant Professor, Department of Kriya Sharir, Government Ayurveda Medical College, Tripunithura, Kerala, India.

3. Retired Principal Government Ayurveda Medical College, Kannur, Kerala, India.

\begin{abstract}
Introduction - Ayurveda gives utmost importance to the maintenance of positive health. Health and longevity in turn depends on bala or inherent strength of the individual. Bala is different in different seasons. Bala is examined as the capacity to do exercise, which is indicative of physical power of an individual. If the reflection of variation of bala on the basis of hematological parameters is identified, then it will provide many possibilities to modify the diet and lifestyle of healthy individuals in order to maintain health in all seasons. This work is a humble effort to analyze the seasonal variations in bala with respect to physiological objective parameters in the settings of Govt. Ayurveda medical college, Kannur, Kerala, India. Methods - In this study 30 healthy individuals between the age group of 20-30 were selected having similar vyayamasakthi- ie, based on the time taken to attain ardhasakthi lakshanas in treadmill test. First assessment was done in adanakaala. Their basic details, dasavidha pareeksha were taken before treadmill test. After 3 days of treadmill test, blood investigations were analyzed. The same procedure was done in visarga kaala also.Results - On the basis of analysis, the bala assessed by vyayamasakthi in visarga kaala was increased than adana kaala. Hemoglobin and HDL cholesterol were increased and serum calcium was decreased in visarga kaala. Considering vital parameters, increase in pulse rate, heart rate, systolic and diastolic BP was noticed in visarga kaala; all within physiological limits. Discussion - Bala was decreased in adana kaala due to the intensity of sunrays and intense dry wind. It causes decreased time to attain the ardhasakthi lakshana. Sweat occurs early. The bala was higher in visarga kaala compared to adaana kaala.
\end{abstract}

Key Words: Bala, Vyayama, Adana, Visarga, Seasonal variations.

\section{Introduction}

Ayurveda gives priority to preventive medicine and improving body strength. In this covid-19 epoch, immunity and bala are the most discussed topics. Although description of vyadhikshamatwa, ojas, bala etc. are available in the literature (1), it is not enough to meet the needs of changing community. So, it is essential to be evidence- based. Ayurvedic seasonal regimens have sometimes delivered good results in increasing bala in the individual. The recent progress in the field of science has given ample opportunity to apply the principles in the form of objective parameters to understand the functional process of the living organisms. Blood investigations have paramount importance in assessing the health status of the body. In Ayurveda, detailed description of bala can be seen (2). The significance of change in bala with seasonal variations has not been explored yet. This work includes

\section{* Corresponding Author:}

\section{Bindu K Viswambharan}

Assistant Professor,

Department of Kriya Sharir,

Government Ayurveda College,

Tripunithura-682301, Kerala. India.

Email Id: bindu@ayurvedacollege.ac.in the assessment of bala with respect to vyayamasakthi in two different seasons that is adaana kaala and visarga kaala (3). Decreased bala causes unfavorable progressive changes associated with decline in vigour and vitality. If variation of bala is identified on hematological parameters, it provides many possibilities to modify the diet and lifestyle of healthy individuals in order to maintain health in all seasons. This work was made to analyze the seasonal variation in bala with respect to physiological objective parameters.

\section{Materials and Methods}

The objectives of the study were;

1. To compare the variations in bala with respect to adana and visarga kaala.

2. To find out whether this variation is reflected upon physiological parameters.

Bala was assessed by vyayamasakthi (4).

Vyayama was suggested to be done up to the appearance of ardhasakthi lakshana $(5,6,7,8,9)$ on treadmill. Before conducting the study, a screening test was done on treadmill with a speed of $5 \mathrm{~km} / \mathrm{hr}$ and observed that most of the individuals attained the ardhasakthi lakshana at 9-11 minutes. A list of these individuals was prepared. From that list 30 Healthy individuals were selected. Treadmill test was conducted to assess the bala. Assessments were done in two different seasons. Blood 
investigations were carried out after 3 days of vyayama in 2 different seasons.

First part of the study was conducted in adana kaala (June-15 -July 15). Before undergoing vyayama, prakriti and saara of the subjects were assessed. The vyayamasakthi was determined by taking the average time of attaining ardhasakthi lakshana by making the individual to run on treadmill with a speed of $5 \mathrm{~km} / \mathrm{hr}$ for 3 days under supervision.

\section{Procedure}

Individuals were called early in the morning at 6.30 am and asked to perform vyayama in the treadmill in a well-ventilated room under supervision. Treadmill speed was set as $5 \mathrm{~km} / \mathrm{hr}$. Time taken till ardhasakthi vyayamalakshana was noted. Procedure continued for 3 consecutive days of adana and visargakaala. $1 \mathrm{hr}$ after vyayama the vital parameters were analyzed. After 3 days of vyayama, blood investigations- $\mathrm{Hb}, \mathrm{TC}, \mathrm{DC}$, ESR, FBS, Lipid profile, serum calcium level were analyzed.

\section{Assessment parameters}

The following parameters were recorded in the subjects.

1. Ardhasa sakthi vyayama lakshana

2. Serum Ca

3. Lipid profile

4. Blood routine examination

5. FBS

\section{Ardhasakthi vyayama lakshana}

Ardhasakthi lakshana mentioned by the Acharyas were taken for the assessment. The lakshanas are hridistha vayu vaktram prapadyate (palpitation), mukha sosha (dryness of mouth), sweda pravruthi (perspiration).

Palpitation (10) Table no-1.- When vayu residing in the heart comes up through mouth, it can be considered as a sign of ardhasakthi vyayama lakshana. This lakshana is more or less similar to palpitation.

Mukhasosha- Table no-1. - When the subject feels dryness in the mouth, it can be taken as one of the ardhasakthilakshanas.

Presence of palpitation and Mukhasosha noted as + sign and is considered as ardhasakthi lakshana. Table no-1.

Table No.1. Palpitation and Mukhasosha

\begin{tabular}{|c|c|c|}
\hline Ardhasakthi lakshana & Present $(+)$ & Absent (-) \\
\hline Palpitation & + & \\
\hline Dryness of mouth & + & \\
\hline
\end{tabular}

Swedapravruthi (11) or Perspiration:- Seen over the area of kaksha, lalata, nasa, hastha patadi sandhi etc. When sweat appears on the forehead, nose, joints and axilla can be taken as one of the ardhasakthi lakshana. Table no-2. The area of wetting of filter paper was graded into 4. "+" sign was assigned if $1 / 4$ th of the filter paper became wet, " ++ " for $1 / 2, "+++$ " for $3 / 4$ and " + +++ for complete wetting of filter paper. $\mathrm{A}++$ in perspiration along with palpitation and dryness in mouth was considered as the accomplishment of ardhasakthi lakshana for each day performance.

Table No.2. Perspiration chart

\begin{tabular}{|c|c|c|c|c|}
\hline Site & + & ++ & +++ & ++++ \\
\hline Axilla & + & ++ & +++ & ++++ \\
\hline Fore head & + & ++ & +++ & ++++ \\
\hline Nose & + & ++ & +++ & ++++ \\
\hline Hands & + & ++ & +++ & ++++ \\
\hline $\begin{array}{c}\text { Legs \& other } \\
\text { joints }\end{array}$ & + & ++ & +++ & ++++ \\
\hline
\end{tabular}

The extent of perspiration was measured by placing filter paper in axilla, fore head, nose, hands, legs and other joints during the procedure. For all subjects, filter papers of same batch number were used to ensure same dimension. The area of wetting of filter paper was graded into 4. "+" sign was assigned if $1 / 4$ th of the filter paper became wet, "++" for $1 / 2$, , +++ " for $3 / 4$ and " ++++ " for complete wetting of filter paper.

$\mathrm{A}++$ in perspiration along with palpitation and dryness in mouth was considered as the accomplishment of ardhasakthi lakshana for each day performance. Calculation of the period of reaching ardhasakthi denoted as ' $\mathrm{T}$ ' of each subject was calculated by taking the mean time of ardhasakthivyayama done on treadmill for 3 consecutive days $(\mathrm{T} 1, \mathrm{~T} 2, \mathrm{~T} 3)$ under supervision. That is,

$$
\mathrm{T}=(\mathrm{T} 1+\mathrm{T} 2+\mathrm{T} 3) \div 3
$$

On the next day, $5 \mathrm{ml}$ of venous blood was taken after 12 hours of fasting for the assessment. To maintain the precision and standardization of the results, the routine blood investigations were carried out at clinical laboratory of Govt. Ayurveda College, hospital, Kannur.

Vital parameters, blood pressure, pulse rate, heart rate, respiratory rate etc. were recorded after $1 / 2$ an hour of treadmill test.

\section{Settings}

The study was conducted in Government Ayurveda Medical College, Kannur, Kerala, India.

Sample size -30

\section{Inclusion criteria} individuals.

Age group 20-30 years of male and female

\section{Exclusion criteria}

Systemic illness and on other medications. Individuals who perform exercise regularly.

\section{Results}

Observations regarding the distribution according to age, sex, occupation, diet etc were made in adana and visarga kaala. Statistical analysis was done using SPSS and excel software. Paired t-test was done.

Demographic data-Observation regarding the distribution according to age, sex, occupation, religion, domicile, etc. were made in these two kaalas. 
- Age-Study including 30 individuals, 22(73.33\%) were in the age group of $20-25$ and others $8(26.67 \%)$ were in the age group of 25-30.

- Sex- $6(20 \%)$ males and $24(80 \%)$ females.

- Religion- 93\% were in hindu religion, muslim were 4\% and Christians 3\%.

- Domicile -26 were from rural area and 4 were from urban area.

- Education- 22(73.33\%) had secondary educational qualification and $8(26.67 \%)$ had graduate qualification.

Ayurvedic parameters- Digestive capacity,bowel habit, agni, koshta, prakriti, saara.

Table No.3. Distribution according to digestive capacity

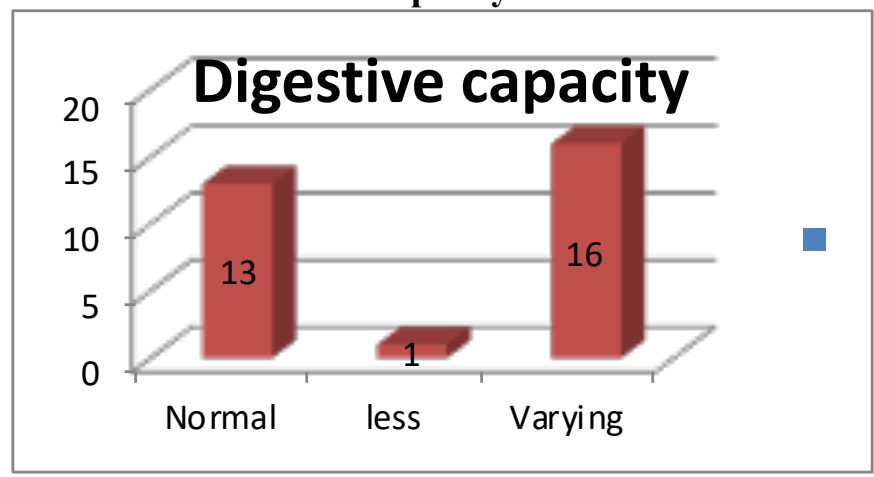

- Digestive capacity - (13) 43.33\% individuals had normal digestive capacity

(16), $53.34 \%$ individuals had varying digestive capacity and (1) $3.33 \%$ individuals had less digestive capacity.

- Sleep- 25(83.33\%) individuals had normal sleep and (5) $16.67 \%$ individuals had disturbed sleep.

- Bowel habit- (25) $83.33 \%$ of individuals had regular bowel habit and (5) 16.67\% individuals had irregular bowel habit.

- Prakriti - (8) $26.67 \%$ individuals belong to vatapitha prakriti, (13) $43.33 \%$ individuals belong to vatakapha prakriti and (9)30\% individuals belong to pithakapha prakriti.

Table no. 4 : Distribution according to prakriti

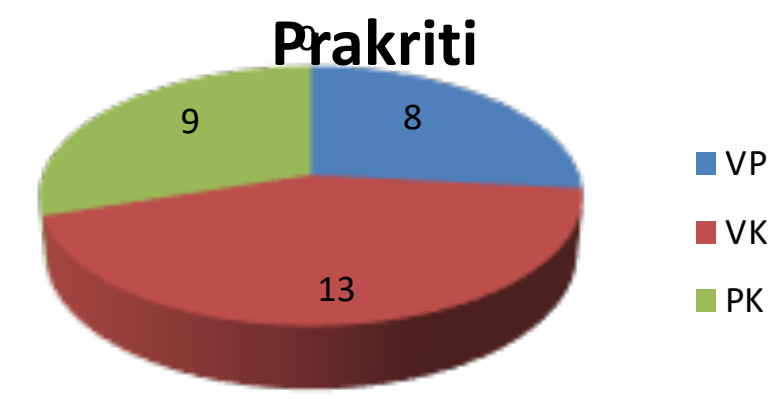

- Saara-14(46.67\%) individuals belong to madhyama saara, (13) $43.33 \%$ belong to avarasaara and (3) $10 \%$ belonged to pravara saara.
- Agni - (10) 33.33\% individuals had samaagni, (13) $43.33 \%$ individuals had vishamaagni, (5) $16.67 \%$ individuals had mandaagni and (2) $6.67 \%$ individuals had teekshnaagni.

Table no. 5: Distribution according to Agni

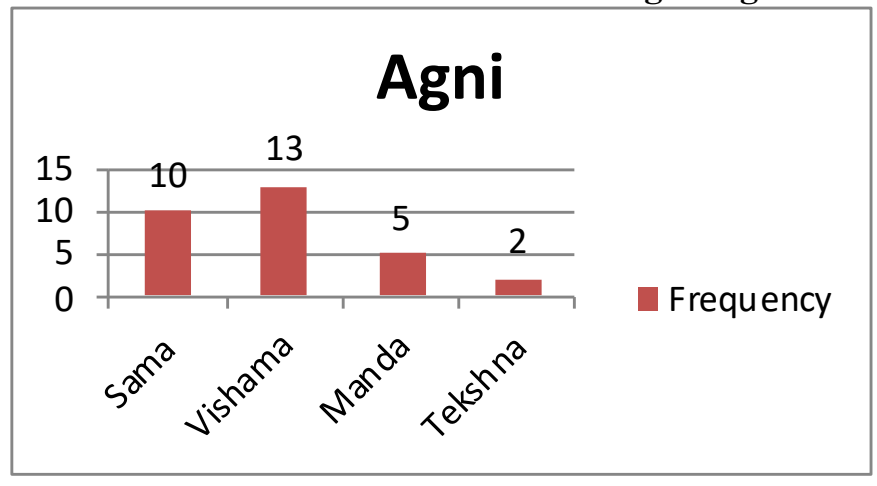

- Koshta - (21)70\% individuals had madhyama koshta, (7) $23.33 \%$ individuals had kroora koshta and (2) $6.67 \%$ individuals had mridu koshta.

Table no. 6: Distribution according to koshta

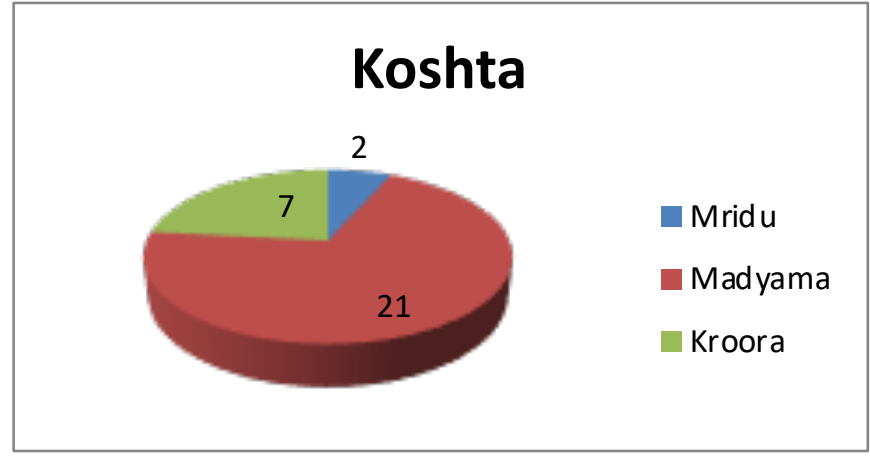

Factors related to bala comparison

- Built - 2 (6.67\%) individuals had well-built body structure, $26(86.66 \%)$ individuals had moderate built structure and2 (6.67\%) were lean.

- BMI - Normal or Healthy individuals (BMI-18.5-24.9) were 18(60\%), underweight individuals (BMI below18.5) were8 (26.67\%), Overweight individuals were $4(13.33 \%)$.

- Muscle bulk - 8 (26.67\%) individuals had muscle bulk (biceps) in between $22-25 \mathrm{~cm}, 16(53.33 \%)$ individuals had the biceps muscle bulk in between 25-29, 6(20\%) individuals had the biceps muscle bulk in between 29-33.

\section{Statistical Analysis}

Analysis of blood parameters

- FBS- The fasting blood sugar in Adana kaala was $88.86 \mathrm{mg} / \mathrm{dl}$ and in visarga kaala, it changed to 89.39 $\mathrm{mg} / \mathrm{dl}$. The difference observed was not statistically significant. $(\mathrm{p}=0.738)$.

- HDL cholesterol - HDL cholesterol in adanakaala was $36.60 \mathrm{mg} / \mathrm{dl}$ and in visargakaala it changed to $38.03 \mathrm{mg} / \mathrm{dl}$. The difference observed was statistically significant. $(\mathrm{p}=0.01)$

- Hemoglobin - Hemoglobin level in adana kaala was $11.71 \mathrm{Gm} \%$ and in visarga kaala it changed to 
$12.24 \mathrm{Gm} \%$. The difference observed was statistically significant $(\mathrm{p}<0.001)$.

- Calcium $\left(\mathrm{Ca}^{2+}\right)$ - Calcium on adana kaala was $9.27 \mathrm{mg} \%$ and in visarga kaala it changed to $8.51 \mathrm{mg} \%$. The difference observed was statistically significant $(\mathrm{p}=0.001)$.

\section{Analysis of Bala}

Bala assessed as time taken to attain ardhasakthi, on adana kaala was 10.18 minute and in visarga kaala it changed to 16.06 minute. The difference observed was statistically highly significant $(\mathrm{p}<0.001)$.

\section{Table No. 7: Effect on Bala}

\begin{tabular}{|c|c|c|c|c|c|c|}
\hline Group & Mean & N & SD & SE & $\begin{array}{c}\text { t- } \\
\text { value }\end{array}$ & $\begin{array}{c}\text { p- } \\
\text { value }\end{array}$ \\
\hline Adana & 10.18 & 30 & 0.82 & 0.15 & -15.21 & 0.00 \\
\hline Visarga & 16.06 & 30 & 2.62 & 0.47 & & \\
\hline
\end{tabular}

Analysis of Vital Parameters

- Systolic blood pressure- Systolic blood pressure on adana kaala was $112 \mathrm{~mm}$ of $\mathrm{Hg}$ and on visarga kaala it changed to $118 \mathrm{~mm}$ of $\mathrm{Hg}$. The difference observed was statistically significant $(\mathrm{p}<0.001)$.

- Diastolic Blood Pressure - Diastolic blood pressure on adana kaala was $72 \mathrm{~mm}$ of $\mathrm{Hg}$ and on visarga kaala it changed to $76 \mathrm{~mm}$ of $\mathrm{Hg}$. The difference observed was statistically significant $(\mathrm{p}=0.001)$.

- Respiratory rate - Respiratory rate in adana kaala was 16.70 and on visarga kaala it was 15.76 . The difference observed was statistically highly significant $(\mathrm{p}<0.001)$.

- Pulse Rate - Pulse rate in adana kaala was 72 and on visarga kaala it was 73 . The difference observed was statistically highly significant $(\mathrm{p}=0.002)$.

\section{Discussion}

Kaala is a continuous entity and it does not have a beginning or end (12). The physical strength as well as the ability of a person to resist disease is termed as bala. It includes certain sahajabhavas like prakriti, saara and satwa which contribute to bala. Sahajabala is unchanged but kaalajabala is changed. Bala acquired through kaala and yukthikrutha aspect have much more importance in maintaining swasthya. Bala is examined as the capacity to do exercise (vyayama) (13).

Vyayama is an important dinacharya mentioned by all Acharyas (14 -17). Benefits, indication and contraindication are explained in classics. It is advised as a therapeutic measure for various diseases and in some disease, it is restricted. Thus, it is not conducive (suitable) to everyone and vyayama must be done with respect to ones bala only. Uthamabala is seen in hemanta and sisira $(18,19)$. In greeshma and varsha body bala is decreased $(20,21)$. Acharya explains that, individuals should perform vyayama up to the appearance of ardhasakti lakshana, otherwise it leads to death (22).

Both Charakacharya and Susrutacharya have explained about rithu. There are two rainy seasons in Kerala's season. According to the opinion of Susruta,vasantha (January- March), greeshma (March-
May) and varsha (May-July) are adana in nature and sarat(July-September), pravrit (September-November), hemanta (November- January) are visarga in nature. Variation in bala also can be seen accordingly. So JuneJuly is the peak of adaana and December- January is the peak of visarga. Bala will be least in between adaana peak and starting of visarga. Bala will be highest in between peak time of visarga and starting of adanakaala. Thus, in order to get maximum variation, the study was conducted in these two periods.

Bala was decreased in adanakaala and increased in visargakaala. Aadanakaala is agneya. The intensity of sunrays and intense dry wind are also the reason for decreased sareerabala. The dehydration, heat and increased dryness all contributed to the decreased time to attain the ardhasakthilakshana in adaanakaala. The sweda sravana function of vyanavata indicates it has a major role in the thermoregulatory mechanism of the body. The hypothalamic pre-optic area has the capacity to serve as a thermostatic body temperature control center. In adana kaala, the atmosphere as well as body temperature is high, the heated blood flows with the help of vyana vata, then the heat regulating centre is stimulated and more sweat is produced. If the hydration of the body decreases during excessive sweating in adana kaala, it will lead to decrease the body strength. So, this may be the reason to decrease the body strength in adana kaala.

\section{Discussion on serum contents}

- Hemoglobin- Hemoglobin value is high in visargakaala. The possible reasons were proper agni in visargakaala lead to the formation of proper aharasaara and development of rakthadhathu. In adanakaala, decreased appetite leads to decreased food intake and it may cause decrease in hemoglobin production. The low value of thyroid hormone in summer compared to winter may came decreased hemoglobin production (23).

- HDL Cholesterol- The mean value of HDL cholesterol in adanakaala was decreased than visargakaala. The difference observed was statistically significant. HDL is anti-atherogenic or protective in nature. HDL is known as good cholesterol. So, increase in good cholesterol in visargakaala indicates the increase in health or bala.

- Calcium- Calcium is decreased in visargakaala than adana. Calcium metabolism in the body is affected by so many factors like diet, blood calcium level and body level calcium. Hormones like calcitonin and parathormone play a role for maintaining the level of calcium in the body. So, increase of calcium in adana kaala is due to difference in calcium metabolism along with the probable dietetic changes and due to the exposure of sunlight and subsequent changes in vitamin D and Calcium absorption.

- Bala (Ardha sakthi vyayama lakshana) -The bala in visarga kaala was increased than adana kaala. The difference was statistically significant. Ardhasakthi vyayama lakshana like sweating, palpitation and dryness of mouth was attained more early in adana than visarga. The intensity of heat of sunrays and dry 
wind was more in adana kaala than visarga kaala. Palpitation means oxygen consumption during exercise. More water and electrolyte is lost in adana than in visarga from our body (24). On hot climate more sweat was produced. Sweat contains large amount of salt and water. Due to the salt loss and water loss, the dryness of mouth in adana kaala was seen more easily than visarga kaala. So, the bala was decreased in adana kaala.

- The vital parameter's difference was within the physiological limits. Recent studies shown that moderate exercise boost the immune system. Acute exercise is an immune system adjuvant that improves metabolism (25). After the end of exercise, immune system generally returns to normal within few hours. Constant regular exercise makes these changes more long lasting. Habitual exercise improves immune regulation and delayed the aging process. Certain diseases are decreased due to regular, controlled and moderate exercise. Eg:- Diabetes mellitus, chronic coronary occlusive heart disease, osteoarthritis.

\section{Limitations}

Since there are no previous studies available, this was a pilot study and the observations seen need to be tested in a bigger sample.

The variations obtained was very less except for the time taken to attain ardhasakthilakshana.

\section{Suggestion}

Interventional studies on various aspects can be planned taking the trend observed in this study into consideration

Using the variations obtained, the exact sample size needed to test the relevance of each parameter can be fixed for further studies.

\section{Conclusion}

This study showed that bala can be assessed by standardized procedure of ardhasakthi vyayama lakshana. Ardhasakthi vyayama depends on the environmental temperature, humidity and evaporative mechanism of the body. The suprachiasmatic nucleus of the hypothalamus play a central role in day today variations and changing cycles of day and night and variety of physiological, endocrine and behavioral process in humans. Constant regular moderate exercise boosts the production of macrophages which kill the bacteria and viruses and has therapeutic effect. The time taken to attain sweating is comparatively less in adana than in visarga kaala. The bala was higher in visarga kaala compared to adaana kaala. The mean values of heart rate, pulse rate, hemoglobin \%, systolic BP, diastolic BP and HDL cholesterol were increased in visarga kaala than adaana kaala. The changes in all the variables - blood pressure, heart rate, pulse rate and serum contents were increased or decreased within physiological limit.

\section{Reference}

1. Srikantha Murthy KR. (trans). Ashtanga Hridayam of Vagbhatas Chikitsa sthanam Chapter 1,Verse no-99., Chowkhamba Krishnadas Academy, Varanasi, 2018, p-173.

2. Sharma Ram Karan, Bhagwan Dash editors Caraka Samhita Sutra sthanam of Agnivesa's text Volume-1, Chapter-2, Verse-36, Chowkhamba Sanskrit series, Varanasi,2014, p-220.

3. Sharma Priya Vrat, editor, Susruta Samhita Uttarathantra with Dalhana's Commentary , 2014, Volume-3, Chowkhambha Viswabharati Oriental Publishers, Varanasi, Chapter-64, Verse no-32,33,34, p-624.

4. Sharma Ram Karan, Bhagwan Dash, editors. Caraka Samhita, Volume2, Vimana sthanam, Trividha roga visesha vijnaneeya vimana. Chapter-4, Verse-8. Chowkhamba Sanskrit series, Varanasi, 2014.p.166.

5. Sharma Priya Vrat, editor, Cikitsa sthanam of Susruta Samhita, 2013, Volume-2, Chowkhambha Viswabharati, Varanasi, Chapter-24, Verse no-47,48, p-227.

6. Sharma Ram Karan, Bhagwan Dash editors Caraka Samhita Sutra sthanam 2014, Volume-1, Chowkhamba Sanskrit series, Varanasi, Chapter-7, Verse no-32,33,34, p-152.

7. Kumari Asha, Tewari Premavati, editors, Yogaratnakara 2010, Chaukhambha Viswabharati, Varanasi, Part 1, Chapter-1, Verse no-544, p-69.

8. Sitaram Bulusu, Commentator, Bhavaprakasha of Bhavamisra, original text along with commentary and translation, edition- Reprint 2012, Part-1, Chapter-5, Verse no-52,53, p-71.

9. Srikantha Murthy KR. Translator Ashtanga Hridayam Sutrasthanam, 2011, Volume-1, Chowkhamba Krishnadas Academy, Varanasi, Chapter 2,Verse no-11, p-24.

10. Sharma Priya Vrat, editor, Cikitsa sthanam of Susruta Samhita, 2013, Volume-2, Chowkhambha Viswabharati, Varanasi, Chapter-24 Anagadabadha, Verse no-47, p-227.

11. Sharma Ram Karan, Bhagwan Dash editors Caraka Samhita Sutra sthanam, 2014, Volume-1, Chowkhamba Sanskrit series, Varanasi, Chapter-7,Verse no-32,33,34, p-152.

12. Sharma Priya Vrat, editor, Susruta Samhita Sutrasthana, 2013, Volume-1, Chowkhambha Viswabharati Oriental Publishers, Varanasi, Chapter-6, Verse no-2, p-73.

13. Sharma Ram Karan, Bhagwan Dash, editors. Caraka Samhita, Volume2, Vimana sthanam, Trividha roga visesha vijnaneeya vimana. Chapter-4, Verse-8. Chowkhamba Sanskrit series, Varanasi, 2014.p.166, p-166.

14. Kumari Asha, Tewari Premavati, editors, Yogaratnakara, 2010, Chaukhambha Viswabharati, Varanasi, Part 1, Chapter-1, Verse no-544, P-69.

15. Srikantha Murthy KR. Translator Ashtanga Hridayam Sutra sthanam, 2018, Chowkhamba 
Krishnadas Academy, Varanasi, Chapter 2,Verse no-10, p-24.

16. Sharma Priya Vrat, editor, Cikitsa sthanam of Susruta Samhita, 2013, Volume-2, Chowkhambha Viswabharati, Varanasi, Chapter-24 Anagadabadha, Verse no-38,39,40, P-227.

17. Sitaram Bulusu, Commentator, Bhavaprakasha of Bhavamisra, 2012, Part-1, Chapter-5, Verse no-52,53, p-71.

18. Sharma Priya Vrat, editor, Susruta Samhita Sutrasthana, 2013, Volume-1, Chowkhambha Viswabharati Oriental Publishers, Varanasi, Chapter-6, Verse no-7, p-76.

19. Srikantha Murthy KR. Translator Ashtanga Hridayam Sutrasthanam, 2011, Volume-1, Chowkhamba Krishnadas Academy, Varanasi, Chapter 3,Verse no-5,6,p-34.

20. Srikantha Murthy KR. Translator Ashtanga Hridayam Sutrasthanam, 2011, Volume-1, Chowkhamba Krishnadas Academy, Varanasi, Chapter 3,Verse no-2,6, p-34.

21. Sharma Priya Vrat, editor, Susruta Samhita Sutrasthana, 2013, Volume-1, Chowkhambha
Viswabharati Oriental Publishers, Varanasi, Chapter-6, Verse no-7, p-76.

22. Srikantha Murthy KR. Translator Ashtanga Hridayam Sutrasthanam, 2011, Volume-1, Chowkhamba Krishnadas Academy, Varanasi, Chapter 2,Verse no-14, p-25.

23. Tae Hyuk Kim, Kyung Won Kim, Hwa Young Ahn, Hoon Sung Choi, Hojeong Won, Yunhee Choi, Sun Wook Cho, Jae Hoon Moon, Ka Hee Yi, Do Joon Park, Effect of Seasonal Changes on the Transition Between Subclinical Hypo thyroid and Euthyroid Status. J Clin Endocrinol Metab. 2013 August;98(8):PMID :23771919. https://doi.org/ 10.1210/jc.2013-1607.

24. Guyton Arthur C, Hall John E. Text book of Medical Physiology, Eleventh edition, U.P.India, Elsvier India Private Limited, Gopsons paper limited 1999.Unit 15- Sports physiology- Body fluids and salt in exercise- P- 1065.

25. David Christopher Nieman, Laurel Wentz, The compelling link between physical activity and the body's defence system: Journal of Sport and Health Science. 2019 May;8(3):201-215. https://doi.org/ 10.1016/j.jshs.2018.09.009. 